\title{
Effect of Quenching and Partitioning Temperatures in the Q-P Process on the Properties of AHSS with Various Amounts of Manganese and Silicon
}

\author{
Hana Jirková ${ }^{1, a}$, Ludmila Kučerová ${ }^{1, b}$ and Bohuslav Mašek ${ }^{1, c}$ \\ ${ }^{1}$ Research Centre of Forming Technology, University of West Bohemia in Pilsen, Faculty of \\ Mechanical Engineering, Pilsen CZ-30614, Czech Republic \\ ahstankov@vctt.zcu.cz, bskal@vctt.zcu.cz, ${ }^{\text {cm }}$ 'sasekb@vctt.zcu.cz
}

Keywords: Q-P process; AHSS, quenching and partitioning temperature

\begin{abstract}
The use of the combined influence of retained austenite and bainitic ferrite to improve strength and ductility has been known for many years from the treatment of multiphase steels. Recently, the very fine films of retained austenite along the martensitic laths have also become the centre of attention. This treatment is called the Q-P process (quenching and partitioning). In this experimental program the quenching temperature and the isothermal holding temperature for diffusion carbon distribution for three advanced high strength steels with carbon content of $0.43 \%$ was examined. The alloying strategies have a different content of manganese and silicon, which leads to various martensite start and finish temperatures. The model treatment was carried out using a thermomechanical simulator. Tested regimes resulted in a tensile strength of over $2000 \mathrm{MPa}$ with a ductility of above $14 \%$. The increase of the partitioning temperature influenced the intensity of martensite tempering and caused the decrease of tensile strength by $400 \mathrm{MPa}$ down to $1600 \mathrm{MPa}$ and at the same time more than $10 \%$ growth of ductility occurred, increasing it to more than $20 \%$.
\end{abstract}

\section{Introduction}

The combination of high strength and ductility together with low economic demands are today's trends when proposing new steel types. These steels have been mostly developed for the automotive industry with the goal of increasing the safety of individual components while lowering their weight [1]. This also supports the current trend of emission reduction. An important role during processing of these steels is played by retained austenite, which is always present in different types of matrix. For example, it occurs in the ferritic-bainitic matrix of TRIP steels, whilst it is embedded in the martensite matrix in steels processed with the Q-P process. In the case of a combination of retained austenite with martensitic matrix higher strength values can be gained [2]. The appropriate heat treatment, through which the suitable combination of martensite and retained austenite can be obtained, was described for the first time in 2003 [3].

Q-P process (Quenching and Partitioning). Q-P process is a two stage integrated heat treatment, which can be described as follows. After heating to the full austenite field, or to the intercritical area, the steel is then cooled down to a temperature between $M_{s}$ and $M_{f}[2]$. In this first stage it is necessary to select the suitable quenching temperature (QT) in order to obtain the required amount of martensite and to ensure that there is enough austenite retained in the structure. In the second stage the steel is heated to just below the $\mathrm{M}_{\mathrm{s}}$ temperature, and then an isothermic hold at the partitioning temperature (PT) is performed. During this holding time carbon diffuses from the supersaturated martensite into the austenite [1-3].

This treatment depends on the appropriate selection of process parameters and on the suitable alloying strategy, which must hinder the formation of carbides, suppress the pearlitic and bainitic transformation and enable carbon to diffuse into austenite, thereby stabilizing it [1-5]. The most important parameters influencing the retained austenite fraction and thus mechanical properties are the quenching and partitioning temperatures. 
The quenching temperatures highly depend on the carbon content in the steel [6], (Fig. 1). As its amount increases, the quenching temperature drops, while the ability to stabilize a higher austenite content grows. Conversely, with the carbon content decreasing, the interval of temperatures suitable for stabilization distinctively propagates. This creates better premises for the process control in industrial applications.

The ratio between martensite and untransformed austenite in relation to the total carbon content is of great importance. If the austenite fraction is too large, then the carbon available in the structure is insufficient and unable to stabilize it, causing it to partially decompose during the consequent quenching to room temperature.

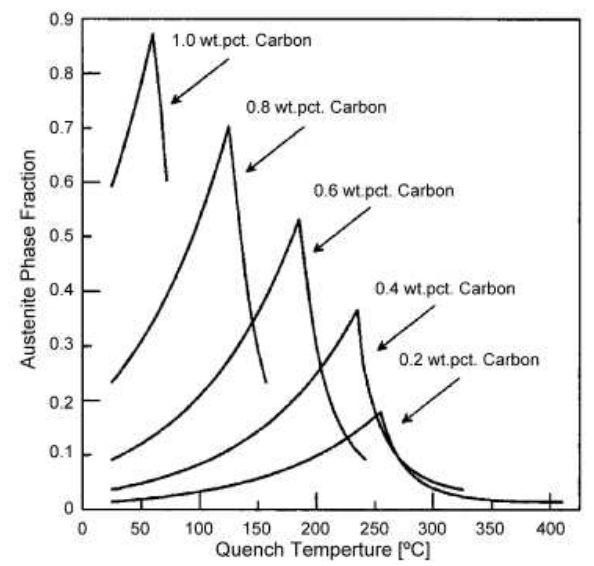

Fig. 1: Assumed RA fraction for various carbon contents [6]

\section{Experimental programme}

The influence of the quenching and partitioning temperatures on the structure development and mechanical properties was examined on three high strength low-alloy (HSLA) steels with various manganese and silicon contents (see Tab. 1).

Tab. 1: Chemical composition of all steel variants

\begin{tabular}{|c|c|c|c|c|c|c|c|c|c|c|c|c|}
\hline Steel & $\mathrm{C}$ & $\mathrm{Si}$ & $\mathrm{Mn}$ & $\mathrm{Cr}$ & $\mathrm{Mo}$ & $\mathrm{Al}$ & $\mathrm{Nb}$ & $\mathrm{P}$ & $\mathrm{S}$ & $\mathrm{Ni}$ & $\begin{array}{c}\mathrm{M}_{\mathrm{s}} \\
{\left[{ }^{\circ} \mathrm{C}\right]}\end{array}$ & $\begin{array}{c}\mathrm{M}_{\mathrm{f}} \\
{\left[{ }^{\circ} \mathrm{C}\right]}\end{array}$ \\
\hline $\mathrm{H} 0$ & 0.43 & 2.03 & 0.59 & 1.33 & 0.03 & 0.008 & 0.03 & 0.009 & 0.004 & 0.07 & 298 & 178 \\
\hline $\mathrm{H} 1$ & 0.43 & 2.6 & 0.59 & 1.33 & 0.03 & 0.008 & 0.03 & 0.01 & 0.01 & 0.01 & 309 & 190 \\
\hline $\mathrm{H} 2$ & 0.43 & 2.6 & 1.17 & 1.33 & 0.03 & 0.008 & 0.03 & 0.01 & 0.011 & 0.07 & 276 & 153 \\
\hline
\end{tabular}

Manganese and silicon play an important role in the transformation control, as well as in the stabilization of retained austenite and hardening of the solid solution [7]. For each of the investigated steels a goal was set to achieve a high tensile strength with a ductility of about 10 to $15 \%$ through a combination of martensite and retained austenite (Fig. 2).

The initial structure was pearlitic with a small ferrite fraction in each case (Fig. 3). The ultimate strength ranged from $810 \mathrm{MPa}$ for material $\mathrm{H} 1$ with higher silicon content to $980 \mathrm{MPa}$ for material $\mathrm{H} 0$.

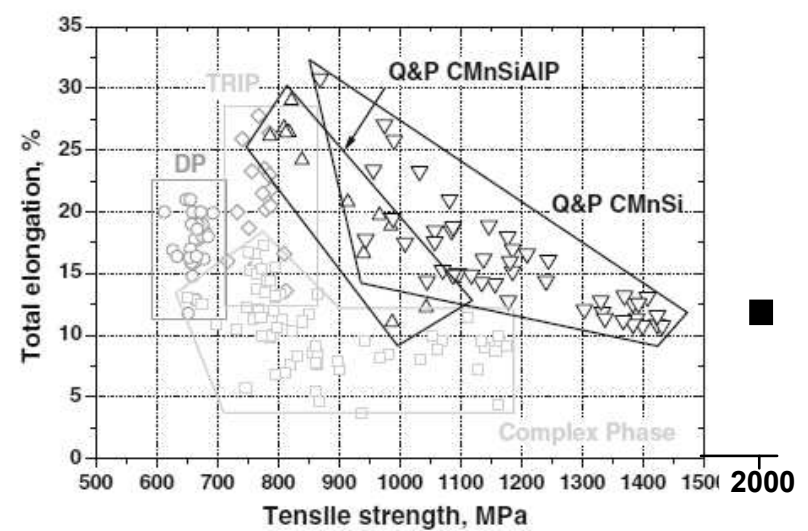

Fig. 2: An overview of various steel types with the experimental material marked [1]

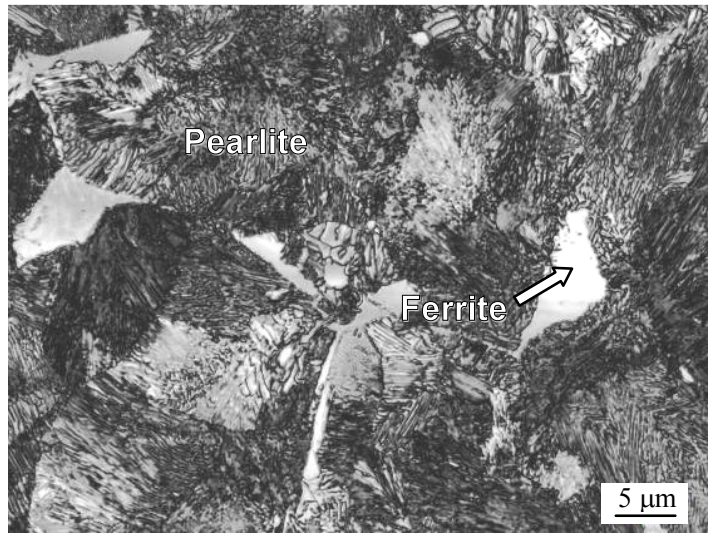

Fig. 3: Initial structure of the H0 steel 
Phase transformation temperatures. In order to be able to propose adequate quenching and partitioning temperatures, Continuous Cooling Transformation (CCT) and Time-Temperature Transformation (TTT) diagrams were set up and $\mathrm{M}_{\mathrm{s}}$ and $\mathrm{M}_{\mathrm{f}}$ temperatures calculated using the JMatPro software (Fig. 4). The calculation was carried out for the austenitizing temperature of $950^{\circ} \mathrm{C}$ and the grain size of $30 \mu \mathrm{m}$. The increase of the silicon content raises the $\mathrm{M}_{\mathrm{s}}$ temperature while fastening it at the same time. Conversely, higher manganese content decreases the $\mathrm{M}_{\mathrm{s}}$ temperature (Tab. 1).

Q-P process modelling. Processing via Q-P process was carried out on a thermomechanical simulator, which enables precise temperature and deformation control. Materials are heated through a combination of induction and resistance heating.

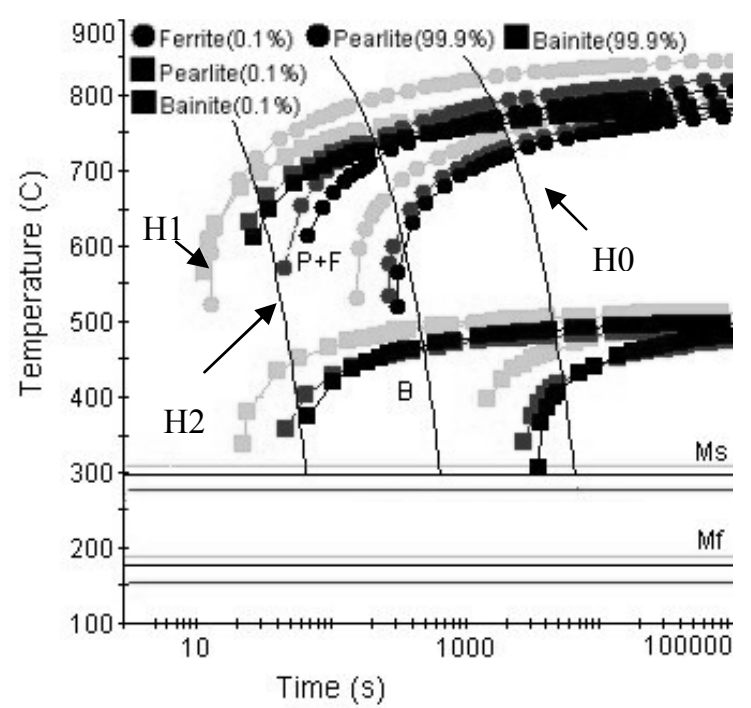

Fig. 4: The influence of $\mathrm{Mn}$ and $\mathrm{Si}$ on the phase transformations

With steels it is possible to achieve a controlled heat and cooling rate of ca. $250^{\circ} \mathrm{C} . \mathrm{s}^{-1}$ with a steep gradient. The temperature is measured by a thermocouple.

The simulated thermomechanical processing with the Q-P process consisted of austenitizing at a temperature of $900^{\circ} \mathrm{C}$ for the $\mathrm{H} 0$ material and at $950^{\circ} \mathrm{C}$ for materials $\mathrm{H} 1$ and $\mathrm{H} 2$ with a holding time of 100 s followed by a twenty step incremental deformation with the accumulated true strain value of $\varphi=5$ within the temperature interval $900-820^{\circ} \mathrm{C}$. This deformation was inserted to achieve a structure refinement. After deformation a cooling to the following quenching temperatures was carried out: $150^{\circ} \mathrm{C}, 175^{\circ} \mathrm{C}, 200^{\circ} \mathrm{C}$ and $250^{\circ} \mathrm{C}$. Immediately afterwards, the material was heated to different partitioning temperatures (Tab. 2). The quenching temperatures $200^{\circ} \mathrm{C}$ and $250^{\circ} \mathrm{C}$ lie for all examined steels within the temperature interval between $\mathrm{M}_{\mathrm{s}}$ and $\mathrm{M}_{\mathrm{f}}$. The temperature of $175^{\circ} \mathrm{C}$ is already below the $\mathrm{M}_{\mathrm{f}}$ temperature for both the $\mathrm{H} 0$ and $\mathrm{H} 1$ steels and the temperature of $150^{\circ} \mathrm{C}$ was tested for the $\mathrm{H} 2$ material only, which has an $\mathrm{M}_{\mathrm{f}}$ temperature of $153^{\circ} \mathrm{C}$.

\section{Results and discussion}

The analysis of the results focused on the influence of the quenching and the partitioning temperatures on the structure development, especially their impact on the formation and stabilisation of retained austenite. The lower the quenching temperature, the greater the martensite fraction within the structure and, at the same time, the smaller the amount of untransformed austenite which can be stabilized by the carbon diffusion. The smaller fraction of retained austenite enables saturation with higher carbon content, thus ensuring the stability of austenite up to room temperature. Therefore, an optimal quenching temperature with respect to the following partitioning had to be found, so that - in the shortest possible time - the largest possible amount of retained austenite could be stabilized.

Quenching temperature in the temperature interval between $\mathbf{M}_{\mathbf{s}}$ and $\mathbf{M}_{\mathbf{f}}$. In the first part of the experiment quenching temperatures of 200 and $250^{\circ} \mathrm{C}$ lying between $\mathrm{M}_{\mathrm{s}}$ and $\mathrm{M}_{\mathrm{f}}$ temperatures were tested. The temperature $250^{\circ} \mathrm{C}$ lies just $26^{\circ} \mathrm{C}$ below $\mathrm{M}_{\mathrm{s}}$ for the $\mathrm{H} 2$ material. It was discovered that the increase of the quenching temperature from 200 to $250^{\circ} \mathrm{C}$ caused a significant reduction of ca. $400 \mathrm{MPa}$ from the ultimate strength values of about $2000 \mathrm{MPa}$, while enhancing the ductility by about ca. 5\% in all cases. Also, the hardness corresponds with this phenomenon, as it decreases with the rising quenching temperature. The ultimate strength was lowered from $2096 \mathrm{MPa}$ at $200^{\circ} \mathrm{C}$ quenching temperature to $1648 \mathrm{MPa}$ at $250^{\circ} \mathrm{C}$ QT for the $\mathrm{H} 0$ material. The highest ultimate strength of $2118 \mathrm{MPa}$ was reached by the $\mathrm{H} 2$ material disposing of the higher amount of both manganese and silicon, while the ductility reached $14 \%\left(\mathrm{~A}_{5 \mathrm{~mm}}\right.$ value $)$. 
The final structure of materials $\mathrm{H} 0$ and $\mathrm{H} 2$ was martensitic and retained austenite was detected in form of a thin film along martensitic needles (Fig. 5). Material H1 with the amount of silicon enriched from 2 to $2.6 \%$ had free ferrite in its structure (Fig. 6).

Tab. 2: Impact of various overcooling temperatures on mechanical properties

\begin{tabular}{|c|c|c|c|c|c|}
\hline Steel & Treatment & $\begin{array}{c}\mathbf{M}_{\mathbf{f}} \\
{\left[{ }^{\circ} \mathbf{C}\right]}\end{array}$ & $\begin{array}{c}\text { HV } 10 \\
{[-]}\end{array}$ & $\begin{array}{c}\mathbf{R}_{\mathrm{m}} \\
{[\mathrm{MPa}]}\end{array}$ & $\begin{array}{c}\mathbf{A}_{5 \mathrm{~mm}} \\
{[\%]}\end{array}$ \\
\hline \multirow{4}{*}{$\mathrm{H} 0$} & $900^{\circ} \mathrm{C} / 100 \mathrm{~s}-250^{\circ} \mathrm{C} / 10 \mathrm{~s}-300^{\circ} \mathrm{C} / 600 \mathrm{~s}$ & \multirow{4}{*}{178} & - & 1648 & 22 \\
\hline & $900^{\circ} \mathrm{C} / 100 \mathrm{~s}-200^{\circ} \mathrm{C} / 10 \mathrm{~s}-250^{\circ} \mathrm{C} / 600 \mathrm{~s}$ & & 546 & 2096 & 12 \\
\hline & $950^{\circ} \mathrm{C} / 100 \mathrm{~s}-175^{\circ} \mathrm{C} / 10 \mathrm{~s}-200^{\circ} \mathrm{C} / 600 \mathrm{~s}$ & & 654 & 1910 & 22 \\
\hline & $950^{\circ} \mathrm{C} / 100 \mathrm{~s}-175^{\circ} \mathrm{C} / 10 \mathrm{~s}-250^{\circ} \mathrm{C} / 600 \mathrm{~s}$ & & 581 & 1669 & 23 \\
\hline \multirow{4}{*}{$\mathrm{H} 1$} & $900^{\circ} \mathrm{C} / 100 \mathrm{~s}-250^{\circ} \mathrm{C} / 10 \mathrm{~s}-300^{\circ} \mathrm{C} / 600 \mathrm{~s}$ & \multirow{4}{*}{190} & 515 & 1630 & 26 \\
\hline & $900^{\circ} \mathrm{C} / 100 \mathrm{~s}-200^{\circ} \mathrm{C} / 10 \mathrm{~s}-250^{\circ} \mathrm{C} / 600 \mathrm{~s}$ & & 570 & 1965 & 17 \\
\hline & $950^{\circ} \mathrm{C} / 100 \mathrm{~s}-175^{\circ} \mathrm{C} / 10 \mathrm{~s}-200^{\circ} \mathrm{C} / 600 \mathrm{~s}$ & & 610 & 1975 & 12 \\
\hline & $950^{\circ} \mathrm{C} / 100 \mathrm{~s}-175^{\circ} \mathrm{C} / 10 \mathrm{~s}-250^{\circ} \mathrm{C} / 600 \mathrm{~s}$ & & 591 & 1857 & 20 \\
\hline \multirow{5}{*}{$\mathrm{H} 2$} & $900^{\circ} \mathrm{C} / 100 \mathrm{~s}-250^{\circ} \mathrm{C} / 10 \mathrm{~s}-300^{\circ} \mathrm{C} / 600 \mathrm{~s}$ & \multirow{5}{*}{153} & 563 & 1711 & 29 \\
\hline & $900^{\circ} \mathrm{C} / 100 \mathrm{~s}-200^{\circ} \mathrm{C} / 10 \mathrm{~s}-250^{\circ} \mathrm{C} / 600 \mathrm{~s}$ & & 644 & 2118 & 14 \\
\hline & $950^{\circ} \mathrm{C} / 100 \mathrm{~s}-175^{\circ} \mathrm{C} / 10 \mathrm{~s}-200^{\circ} \mathrm{C} / 600 \mathrm{~s}$ & & 645 & 2125 & 13 \\
\hline & $950^{\circ} \mathrm{C} / 100 \mathrm{~s}-175^{\circ} \mathrm{C} / 10 \mathrm{~s}-250^{\circ} \mathrm{C} / 600 \mathrm{~s}$ & & 587 & 1829 & 15 \\
\hline & $950^{\circ} \mathrm{C} / 100 \mathrm{~s}-150^{\circ} \mathrm{C} / 10 \mathrm{~s}-200^{\circ} \mathrm{C} / 600 \mathrm{~s}$ & & 636 & 1790 & 11 \\
\hline
\end{tabular}

Quenching temperature under the $\mathbf{M}_{\mathbf{f}}$ temperature. The decrease of the quenching temperature to $175^{\circ} \mathrm{C}$ was tested with two different partitioning temperatures of 200 and $250^{\circ} \mathrm{C}$. The temperature of $175^{\circ} \mathrm{C}$ is very close to the $\mathrm{M}_{\mathrm{f}}$ temperature for material H0. A martensitic structure with an ultimate strength of $1938 \mathrm{MPa}$ and $\mathrm{A}_{5 \mathrm{~mm}}$ ductility of $17 \%$ was obtained. The higher amount of silicon in material $\mathrm{H} 1$ did not cause any significant ultimate strength reduction, although free ferrite was detected in the structure again (Fig. 7). Material H2, which has the lowest $\mathrm{M}_{\mathrm{f}}$ temperature of all the examined steels, reached the highest ultimate strength of $2125 \mathrm{MPa}$ (with ductility $\mathrm{A}_{5 \mathrm{~mm}} 13 \%$ ), becoming the highest value from all the tests carried out so far. The final structure was martensitic without free ferrite. The increase of the isothermic hold temperature to $250^{\circ} \mathrm{C}$ while keeping the low quenching temperature again caused a reduction of ultimate strength.

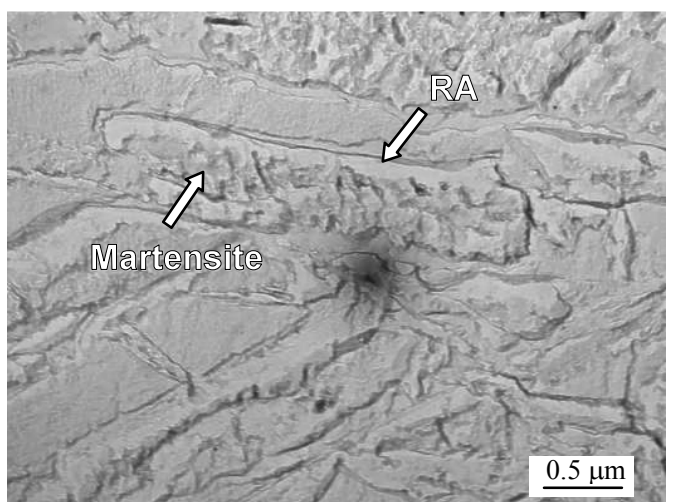

Fig. 5: $\mathrm{H} 0-\mathrm{QT}: 200^{\circ} \mathrm{C} / 10 \mathrm{~s}-\mathrm{PT}: 250^{\circ} \mathrm{C} / 600 \mathrm{~s}$, carbon replica, TEM

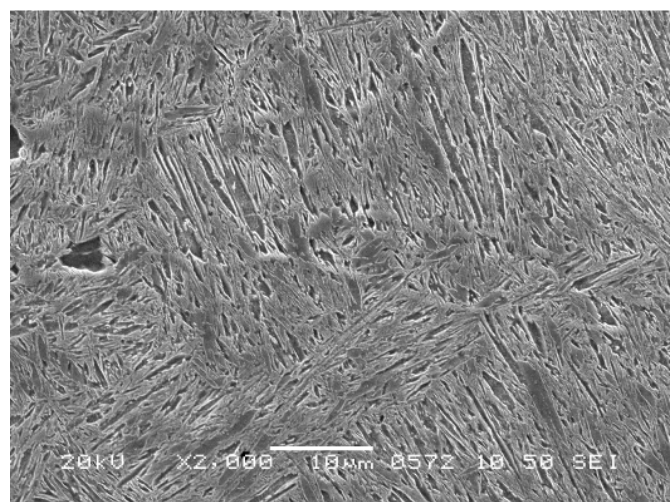

Fig. 6: $\mathrm{H} 1-\mathrm{QT}: 200^{\circ} \mathrm{C} / 10 \mathrm{~s}-\mathrm{PT}: 250^{\circ} \mathrm{C} / 600 \mathrm{~s}$, SEM

Lowering of the quenching temperature to $150^{\circ} \mathrm{C}$ led to worse mechanical properties of the $\mathrm{H} 2$ material compared to the process with a higher quenching temperature. The ultimate strength reached $1790 \mathrm{MPa}$. Interestingly, the ultimate strength of this material did not rise as expected, though the entire volume of the structure probably transformed to martensite. The ductility was over $10 \%$. 


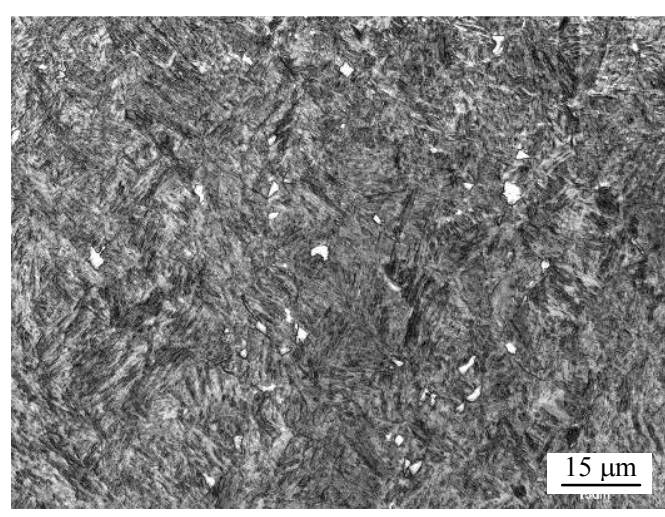

Fig. 7: $\mathrm{H} 1-\mathrm{QT}: 175^{\circ} \mathrm{C} / 10 \mathrm{~s}-\mathrm{PT}$ : $250^{\circ} \mathrm{C} / 600 \mathrm{~s}$, confocal microscopy

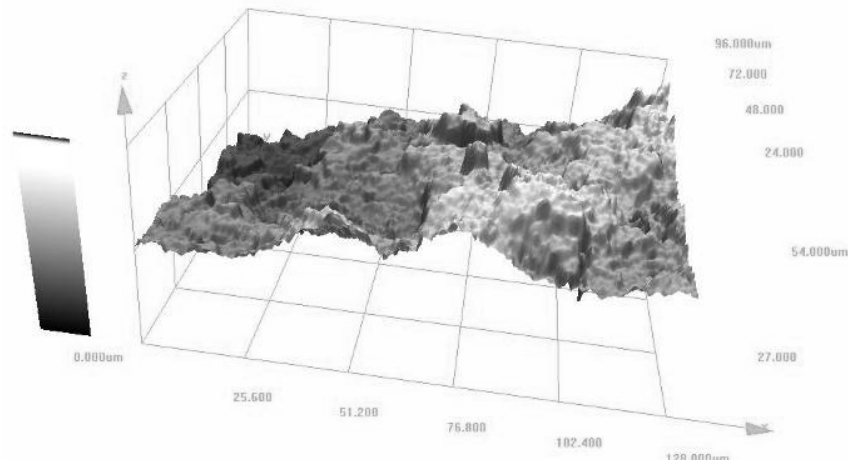

Fig. 8: $\mathrm{H} 2-\mathrm{QT}: 200^{\circ} \mathrm{C} / 10 \mathrm{~s}-\mathrm{PT}: 350^{\circ} \mathrm{C} / 600 \mathrm{~s}$, fracture area $-3 \mathrm{D}$ model - confocal microscopy

Influence of the partitioning temperature. In the second part the influence of the partitioning temperature on the structure development was examined, especially its impact on the retained austenite stabilization. On the basis of previous results the best quenching temperature of $200^{\circ} \mathrm{C}$ was selected and successively tested together with three partitioning temperatures of 250, 300 and $350^{\circ} \mathrm{C}$ (Tab. 3).

Increasing the isothermic hold temperature caused a strength reduction and an increase in ductility in all cases. This phenomenon is the result of higher level martensite tempering and corresponds with hardness values as well (Tab. 3). Higher partitioning temperatures

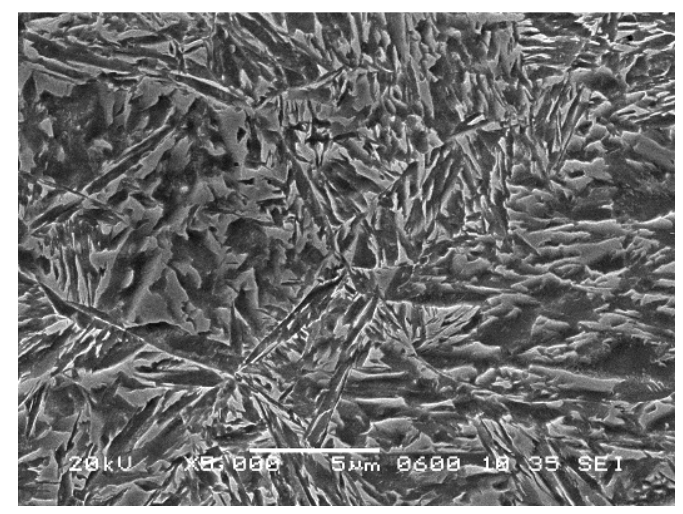

Fig. 9: $\mathrm{H} 2-\mathrm{QT}: 200^{\circ} \mathrm{C} / 10 \mathrm{~s}-$ PT: $350^{\circ} \mathrm{C} / 600 \mathrm{~s}, \mathrm{SEM}$ also contributed to the stabilization of a higher fraction (reaching of $22 \%$ for the material $\mathrm{H} 1$ and the highest PT) of retained austenite. The ultimate strength of material $\mathrm{H} 1$ which was $1965 \mathrm{MPa}$ at $250^{\circ} \mathrm{C}$ decreased to $1702 \mathrm{MPa}$ at $350^{\circ} \mathrm{C}$ while the ductility rose from 17 to $25 \%$. Material $\mathrm{H} 2$ possesses the highest ultimate strength of $2118 \mathrm{MPa}$ with ductility $\mathrm{A}_{5 \mathrm{~mm}}=14 \%$ at $\mathrm{PT}=250^{\circ} \mathrm{C}$ due to higher amounts of manganese and silicon. The fracture was characterized by a ductile failure with a small fraction of brittle fracture after the tensile test (Fig. 8).

Increasing the isothermic hold temperature also had an impact on the character of the microstructure, changing the initial martensitic structure to a tempered martensitic-bainitic structure with significant ferritic fields (Fig. 9).

Tab. 3: Impact of various partitioning temperatures on mechanical properties

\begin{tabular}{|c|c|c|c|c|c|c|c|}
\hline \multirow{2}{*}{ Steel } & Treatment & $\begin{array}{c}\text { PT } \\
{\left[{ }^{\circ} \mathbf{C}\right]}\end{array}$ & $\begin{array}{c}\text { Hold } \\
\text { at PT }[\mathbf{s}]\end{array}$ & $\begin{array}{c}\text { RA } \\
{[\mathbf{\%}]}\end{array}$ & $\begin{array}{c}\mathbf{H V ~ 1 0} \\
{[-]}\end{array}$ & $\begin{array}{c}\mathbf{R}_{\mathbf{m}} \\
{[\mathbf{M P a}]}\end{array}$ & $\begin{array}{c}\mathbf{A}_{\mathbf{5 m m}} \\
{[\mathbf{\%}]}\end{array}$ \\
\hline \multirow{3}{*}{$\mathrm{H} 0$} & 250 & 600 & 17 & 546 & 2096 & 12 \\
\cline { 3 - 8 } & \multirow{3}{*}{$900^{\circ} \mathrm{C} / 100 \mathrm{~s}-200^{\circ} \mathrm{C} / 10 \mathrm{~s}$} & 300 & 600 & 14 & 508 & 1810 & 20 \\
\cline { 3 - 8 } & & 350 & 600 & 17 & 501 & 1703 & 23 \\
\hline \multirow{3}{*}{$\mathrm{H} 1$} & \multirow{3}{*}{$950^{\circ} \mathrm{C} / 100 \mathrm{~s}-200^{\circ} \mathrm{C} / 10 \mathrm{~s}$} & 250 & 600 & 13 & 570 & 1965 & 17 \\
\cline { 3 - 8 } & & 300 & 600 & 19 & 577 & 1757 & 24 \\
\cline { 3 - 8 } & \multirow{3}{*}{$\mathrm{H} 2$} & 350 & 600 & 22 & 558 & 1702 & 25 \\
\hline \multirow{3}{*}{$950^{\circ} \mathrm{C} / 100 \mathrm{~s}-200^{\circ} \mathrm{C} / 10 \mathrm{~s}$} & 300 & 600 & 13 & 566 & 1837 & 22 \\
\cline { 3 - 8 } & & 350 & 600 & 17 & 525 & 1720 & 26 \\
\hline
\end{tabular}




\section{Conclusion}

The influence of the quenching and partitioning temperatures on structure development and mechanical properties was studied for three HSLA steels with the same alloying strategy, but with different contents of manganese and silicon.

Increasing the silicon content from 2 to $2.6 \%$ led to a partial segregation of free ferrite in the quenching structure during the Q-P process and further caused a stabilization of a higher fraction of retained austenite. Up to $20 \%$ of retained austenite was stabilized in some variants. At the same time, this increase of silicon content caused a strength reduction of ca. $100 \mathrm{MPa}$ and an increase of ductility from 12 to $17 \%$ when compared to the initial processing strategy for the H0 steel. The increase of manganese content from 0.59 to $1.17 \%$ in material $\mathrm{H} 2$ resulted in the elimination of free ferrite from the structure, raising the ultimate strength to $2118 \mathrm{MPa}$ with ductility of $14 \%$.

After increasing the overcooling temperature from 200 to $250^{\circ} \mathrm{C}$ the ultimate strength decreased significantly. The ultimate strength of all the materials decreased from about 2000MPa by ca. 300 to $350 \mathrm{MPa}$ in favour of the ductility. The largest ductility $\mathrm{A}_{5 \mathrm{~mm}}=29 \%$ was recorded for the $\mathrm{H} 2$ material with higher silicon and manganese contents. It was further discovered that the time interval during the transition between the quenching temperature and the partitioning temperature also plays an important role. Extension of this interval resulted in worse mechanical properties.

The experiment showed that as the isothermic hold temperature increases, the total amount of stabilized retained austenite in the structure also increases. At the same time however the structure is tempered at a higher level, which leads on the one hand to a certain loss of hardness and strength, but on the other hand it leads to a significant increase of ductility.

Acknowledgement. This paper includes results created within the project GA ČR 106/09/1968 Development of New Grades of High-Strength Low-Alloyed Steels with Improved Elongation Values. The project is subsidised from specific resources of the Czech Science Foundation.

\section{References}

[1] E. De Moor, S. Lacroix, A. J. Clarke, J. Penning, J. G. Speer. Effect of Retained Austenite Stabilized via Quench and Partitioning on the Strain Hardening of Martensitic Steels, Metallurgical and Materials Transactions A, 39A (2008) 2586-2595.

[2] D.V. Edmonds et al. Quenching and partitioning martensite - A novel steel heat treatment, Materials Science and Engineering A. 438-440 (2006) 25-34.

[3] A. J. Clarke et al. Carbon partitioning to austenite from martensite or bainite during the quench and partition (Q-P) process: A critical assessment, Acta Materialia. 56 (2007) 16-22.

[4] B. Mašek, H. Jirková, D. Hauserová, L. Kučerová, D. Klauberová. The Effect of Mn and Si on the Properties of Advanced High Strength Steels Processed by Quenching and Partitioning, Materials Science Forum. 654-656 (2010)94-97.

[5] Klauberová, D. et al. Influence of Deformation Intensity and Cooling Parameters on Microstructure Development in QP Process, Proceedings of the 21st DAAAM International Symposium Intelligent Manufacturing \& Automation (2010), B. Katalinic (Eds.), 743-744.

[6] F. L. H. Gerdemann. Microstructure and hardness of 9260 steel heat/treated by the quenching and partitioning process, Diploma Thesis, Aachen University of Technology, Germany (2004).

[7] W. Bleck. Using the TRIP effect - the dawn of a promising group of cold formable steels, in International Conference on TRIP - Aided High Strength Ferrous Alloys (2002), B. C. De Cooman, (Eds.), Bad Harzburg, GRIPS, 13-25. 